\title{
IAMJ
}

INTERNATIONAL

AYURVEDIC

MEDICAL JOURNAL

\section{CLINICAL EVALUATION OF THE SHODHANA EFFECT OF HARIDRA TAILA AND ROPANA EFFECT OF MADHU IN DUSHTA VRANA}

\author{
Rathore Garima ${ }^{1}$, Gupta Sachin², Rajput Bislesh Kumar ${ }^{3}$ \\ ${ }^{1}$ Assistant Professor, Dept. of PTSR, Motherhood Ayurved College, Roorkee, Uttarakhand, India \\ ${ }^{2}$ Professor, ${ }^{3}$ Assistant Professor, Dept. of Shalya Tantra, Patanjali Bhartiya Ayurvigyan Evum Anusandhan \\ Sansthan, Haridwar, Uttarakhand, India
}

Corresponding Author: gpsingh2009.13@gmail.com

\section{https://doi.org/10.46607/iamj01p5042021}

(Published Online: May 2021)

Open Access

(C) International Ayurvedic Medical Journal, India 2021

Article Received: 28/04/2021 - Peer Reviewed: 11/05/2021 - Accepted for Publication: 12/05/2021

\section{Check for updates}

\section{ABSTRACT}

The presence of Dushta Vrana (non-healing ulcer) worsens the quality of life of the patient with various complications and may prove fatal. Although Vrana is the oldest known ailment and its healing is still a matter of concern. When it refuses to heal despite of best efforts or due to improper treatment of Chikitsachatushpada (four parts necessary for treatment) it turns to DushtaVrana. Chronic wounds of mixed aetiologies showed a pooled prevalence of 2.21 per 1000 population. Its high prevalence worldwide, chronicity and expensive treatment is still a matter of concern. Every research done has a cause. The aim of present research work to provide an economical treatment with least side-effects and in comparatively less time. A clinical trial was conducted in this study group of 30 patients diagnosed with Non-Healing Ulcer (DushtaVrana). Patients were selected randomly irrespective of their age, sex, religion, race, occupation etc. Their Vrana were dressed in Hraidra Taila and Madhu daily till the Vrana heals or for three months maximum and monitored at every 15 days interval during the study period. Symptoms like pain and signs likesize, tenderness, discharge, depth of ulcer, granulation tissue floor were used as parameters to assess the effect of the treatment on Dushta Vrana. Analysis of result showed improvement in DushtaVrana (non-healing ulcer). On the basis of clinical observations, it can be concluded that in the present 
clinical study result of Shodhana (cleansing) effect of Haridra Taila and Ropana (healing) effect of Madhu is very effective.

Keywords Dushta Vrana, Haridra Taila, Madhu.

\section{INTRODUCTION}

To heal is nature's response. Acharya Sushruta has dedicated various chapters of Sutrasthana $\left(1^{\text {st }}\right.$ part of Sushruta Samhita) and few of Chikitsasthana (fourth part of Sushruta Samhita) for the study of whole science of the wound. He has talked about Sadyovrana (fresh wound) and its healing in chikistasthana ${ }^{I}$. When a wound fails to heal even after the best efforts of chikitsachatushpada ${ }^{2}$ (Vaidya (doctor), Aushadh (medicine), Paricharak (attendant) and Rogi (Patient) either due to some underlying pathology or improper • treatment is known as DushtaVrana. It is not easy to eradicate wound. Every surgery begins with a wound. Accidents and wars since very ancient times were the causes of wounds. Recently road traffic accidents have increased the incidence of wound many times.

In Sushruta Samhita lot of description is available regarding the wound and its management under the 1 . heading of Vrana. In Chikitsa Sthana he has described about Shasti Upkrama ${ }^{3}$ (60 treatment modalities for the treatment of ulcer) where he has mentioned about use of different oil for application for shodhana 4 and Madhu for Ropana. Haridra is mentioned as vranapaha (eradicates wound) by Acharya Bhavprakash ${ }^{6}$. Katu and Tikta Rasa, Ushna Veerya, Katu Vipak, Aampachan Guna, Raktshodhaka Guna of Haridra ${ }^{7}$ helps in Shodhana of Dushtavrana. Madhu is kept in Sandhaneya Gana by Acharya Sushruta. These two Dravyas (article) has been used since long for wound healing.

Dushta Vrana is major point of concern for health. Since the ancient time there are continuous and vigorous attempts made for better wound healing over past two thousand years. With the various advancement in molecular and cellular biology research, objective as- . sessment of tissue repair has become more and more sophisticated. India being a country with larger population and a still developing nation the poverty does not allow every patient to reach a sophisticated and expensive treatment. Keeping above facts in mind the present clinical study "Clinical evaluation of the Shodhana effect of Haridra Taila and Ropana effect of Madhu in DushtaVrana" has been done.

\section{Aim \& Objectives:}

"Clinical evaluation of the Shodhana effect of Haridra Taila and Ropana effect of Madhu in Dushta Vrana"

To cure the disease in less time.

To give complication free therapy.

To explore literature about DushtaVrana in Modern as well as Ayurved.

Materials \& Methods: The present study is entitled with "The Shodhana effect of Haridra Taila and Ropana effect of Madhu in Dushta Vrana'.

\section{Materials}

1. Patients suffering from Dushta Vrana. Haidra Taila and Madhu

A. Selection of The Patients: 30 Patients of nonhealing wound were selected from the O.P.D./I.P.D. of Patanjali Ayurved Hospital, Haridwar. Most of the cases were registered as OPD patients. The cases were recorded with the help of special proforma prepared for this study. The patients were treated with Haridra Tail for Shodhana and Madhu for Ropana of DushtaVrana.

B. Selection of Drug: $\mathrm{CO}_{2}$ extracted Haridra Taila for Shodhana and Madhu for Ropana

C. Duration of Study -90 days

D. Type of Study- Open and Prospective Study

E. Selection of Patients

Inclusion Criteria:

Patient aged between 18-70 years

Patient willing to undergo trial and ready to give informed and written consent.

- Patient irrespective of age, sex, religion, socioeconomic status and occupation will be taken. 
- Patient with the clinical features of Dushta Vrana.

- Traumatic ulcers

- Arterial ulcers

- Venous ulcers

- Neurogenic ulcers

- Diabetes ulcers (DM under control)

Exclusion Criteria:

- Patient not willing to undergo trial or not ready to give informed and written consent.

- HIV or Hepatitis B or Hepatitis C positive patients.

- Patients with evidence of malignancy and malignant ulcer

- Tubercular ulcer

- Syphilitic ulcer

- Soft chancre sores (Ducrey's)

- Diabetes mellitus (uncontrolled)

- Patients suffering from chronic renal disease.

Investigations

- Routine blood examination

- Routine urine examination

- Blood sugar fasting and post prandial

- LFT

- KFT

- X-Ray of the part to look for osteomyelitis (if required)

- Culture and sensitivity of the pus (if required)

- VDRL (if required)

- Any other necessary investigations

Drugs selected for Study: $\mathrm{CO}_{2}$ extracted Haridra Taila and Madhu

Procedure of preparation of supercritical $\mathrm{CO}_{2}$ extracted Haridra Taila $^{8}$ : It consists mainly of a high pressure pump, a $\mathrm{SCO}_{2}$ generator vessel, two $1000 \mathrm{~mL}$ Extractors (each of $42 \mathrm{~cm}$ height and $5.5 \mathrm{~cm}$ inside diameter) and two low pressure $1000 \mathrm{~mL}$. Separators, and a low temperature $\mathrm{CO}_{2}$ storage and a Control Unit to view and change the system setting.

Operational Procedure: The operational procedure used in this SFE module was described in detail by S.Roy et al . Initially a particular type of feed shell was filled in full of comminute turmeric samples and placed inside the extractor vessel to carry the runs.
Pressurized solvent $\mathrm{CO}_{2}$ from the pump was allowed to enter the extractor vessel through $\mathrm{SCO}_{2}$ generation vessel to attain the desired extraction pressure. Once the extractor pressure was stabilized, the extract laden $\mathrm{SCO}_{2}$ was expanded to reduce the pressure and recover the essential oil through two successive separators. In the procedure extraction was continued for a period of 240 minutes and the samples were collected and weighed at intervals of $15,30,45,60,90,120,150$, 180, 210 and 240 minutes using separate sampling bottles and recorded to construct over all construction curve. This SFE unit was equipped with a solvent $\mathrm{CO}_{2}$ recovery system and the recovered solvent was returned back to the low temperature $\mathrm{CO}_{2}$ storage vessel for reuse. After extraction total yield was centrifuged and the pure essential oil part was separated and stored in refrigerator unit.

\section{Mode of Application}

- Local application of Haridra Taila for dressing once daily.

- After appearance of healthy granulation tissue application of Madhu on ulcer daily.

Methodology: It is an open and prospective clinical trial. Thorough history and the complaints of the patients were taken in the chronological order. Each and every patient was carefully examined clinically for general and systemic examination. Full explanation about the trial was given to the patients and their attendants and informed consent of each and every patient was taken before the commencement of the treatment after. Total 30 patients were selected for the present clinical trial on the basis of clinical diagnosis.

Study Design: It is an Open and Prospective study

Duration of Study - 90 days

Criteria for Assessment: Assessment was done on the basis of improvement in following signs and symptoms of Non-Healing Wound

Subjective Parameters: Pain

Objective Parameters:

- Size (by using sterile blotting paper)

- Tenderness

- Discharge

- Depth of ulcer

- Granulation tissue floor 


\section{Subjective parameters:}

1. Pain

\begin{tabular}{l|l|}
\hline Grading \\
\hline $\mathbf{0}$ \\
\hline $\mathbf{1}$ \\
\hline $\mathbf{2}$ \\
$\mathbf{3}$
\end{tabular}

\section{Criteria \\ No Pain \\ Localized feeling of pain during movement only but no feeling during rest. \\ Localized feeling of pain even during rest but not disturbing sleep. \\ Localized continuous feeling of pain, radiating and not relieved by rest.}

\section{Objective parameters:}

1. Size

\section{Grading}

0

1

2

\section{Criteria}

No ulcer

Less than $5 \mathrm{~cm}$

Within $5-10 \mathrm{~cm}$

It was recorded by using a sterile blotting paper which was placed over the ulcer and pressed with uniform pressure. The impression was measured directly.

\section{Tenderness}

\begin{tabular}{l|l|l|}
\hline Grading \\
\hline $\mathbf{0}$ \\
\hline $\mathbf{1}$ \\
\hline $\mathbf{2}$ \\
$\mathbf{3}$
\end{tabular}

\section{Criteria}

Tolerance to pressure

Little response to pressure

Wincing effect on super slight touch

Resist to touch and rigidity

3. Discharge

\begin{tabular}{|l|l|}
\hline Grading & Criteria \\
\hline $\mathbf{0}$ & No discharge/dry dressing \\
\hline $\mathbf{1}$ & Scanty occasional discharge and little wet dressing \\
\hline $\mathbf{2}$ & Often discharge and with blood on dressing \\
\hline $\mathbf{3}$ & Profuse, continuous discharge \\
\hline
\end{tabular}

4. Depth of ulcer - The depth was measured with the help of sterile probe.

\begin{tabular}{|l|l|}
\hline Grading & Criteria \\
\hline $\mathbf{0}$ & Healed \\
\hline $\mathbf{1}$ & Less than $0.5 \mathrm{~cm}$ \\
\hline $\mathbf{2}$ & Within $0.5-1.5 \mathrm{~cm}$ \\
\hline $\mathbf{3}$ & $>1.5 \mathrm{~cm}$ \\
\hline
\end{tabular}

\section{Floor and granulation tissue}

\begin{tabular}{|l|l|}
\hline Grading & Criteria \\
\hline $\mathbf{0}$ & Red granulation tissue \\
\hline $\mathbf{1}$ & Pale and smooth granulation tissue \\
\hline $\mathbf{2}$ & Patchy granulation tissue \\
\hline $\mathbf{3}$ & Slough \\
\hline
\end{tabular}


Assessment of Results: The treatment effect was assessed every 15 days on the basis of the relief of signs and symptoms of the disease on scoring pattern by a specially designed proforma.

\begin{tabular}{|l|l|l|}
\hline Sr. No. & Result & Criteria \\
\hline 1. & Healed & $100 \%$ relief in signs and symptoms. \\
\hline 2. & Markedly healed & $76-99 \%$ relief in signs and symptoms. \\
\hline 3. & Moderately healed & $51-75 \%$ relief in signs and symptoms. \\
\hline 4. & Mild improvement & $26-50 \%$ relief in signs and symptoms. \\
\hline 5 & No improvement & $<25 \%$ relief in signs and symptoms. \\
\hline
\end{tabular}

Assessment of the effect of treatment was done on the basis of above given assessment criteria before and after treatment schedule.

Statistical Analysis: The information regarding demographic data was given in percentage. The data obtained in clinical study is subjected to statistical tests and analyzed as in terms of Mean (X), standard deviation (S.D.), standard error (S.E.), Friedman's test $\&$ Wilcoxan sign rank test finally result were incorporated in term of probability ' $\mathrm{P}$ ' as-

$\mathrm{P}>0.050 \quad$ Not significant

$\mathrm{P}<0.010 \quad$ Significant

$\mathrm{P}<=0.001 \quad$ Highly significant

\section{Observations}

* The demographic profile shows that maximum number of patients i.e. $30 \%$ were in between 45 60 years.

* There were more of male patients $(76 \%)$ in the study.

* The number of Hindu patients (97\%) were more.

* Maximum number of patients were graduate
$(46.6 \%)$.

* Maximum number of the patients $(20 \%)$ belong to service class.

* Maximum number of the patients $76.66 \%$ were married.

* Majority of patients (90\%) belonged to medium socioeconomic status.

* Majority of patients $(80 \%)$ are dwelling in urban area.

* On analysis of Prakriti greater part (50\%) of the patients were Vata-Paittik in Prakriti.

* $20 \%$ of patients were addicted to smoking.

* $63.34 \%$ of patients were on mixed diet.

* $76.66 \%$ of patients were married.

* Maximum number of patients $83.33 \%$ suffered Vrana at lower limb

* Maximum number of Dushta Vrana are Adhishtit on Mamsa Dhatu (66.67\%).

* $46.66 \%$ of patients had no addiction probably due to unacceptance.

Table 1: Distribution of patient according to symptom and signs-

\begin{tabular}{|l|l|l|l|}
\hline Sr. no & Symptom & Number of patients & Percentage \\
\hline 1 & Pain & 27 & $90 \%$ \\
\hline 2 & Size & 30 & $100 \%$ \\
\hline 3 & Discharge & 30 & $100 \%$ \\
\hline 4 & Tenderness & 29 & $96.66 \%$ \\
\hline 5 & Depth & 30 & $100 \%$ \\
\hline 6 & Floor & 30 & $100 \%$ \\
\hline
\end{tabular}

Table no. 1 shows the percentage of most commonly seen features in Dushta Vrana in all patients. In the present clinical study total $90 \%$ patient were found suffering with pain. Size was observed in $100 \%$ pa- tients. Discharge was observed in $100 \%$ patients. Tenderness was found in $96.66 \%$ patients. Depth was observed in $100 \%$ patients. Patients with floor with unhealthy granulation tissue were $100 \%$. 
Result: The Data gathered and compiled from this clinical trial was sorted out and processed further by subjection to varied statistical methods and presented in the following sequence. Result of therapy was statistically analysed by Friedman's test and Wilcoxan sign rank Test. The results are:

Table 2: Summarised results after completion (90 days) of treatment:

\begin{tabular}{|l|l|l|l|l|}
\hline Parameters & Wilcoxon signed rank W & P value & $\%$ effect & Result \\
\hline Pain & -4.631 & $=<0.001$ & $83.63 \%$ & Highly Significant \\
\hline Size & -4.878 & $=0.03$ & $75 \%$ & Significant \\
\hline Tenderness & -4.779 & $=<0.001$ & $90.5 \%$ & Highly Significant \\
\hline Discharge & -4.787 & $=<0.001$ & $92.6 \%$ & Highly Significant \\
\hline Depth of ulcer & -4.730 & $=<0.02$ & $79.8 \%$ & Significant \\
\hline Granulation tissue floor & -4.968 & $=<0.001$ & $95 \%$ & Highly Significant \\
\hline
\end{tabular}

Table no 2 shows the percentage of relief. The observations made here are on ordinal scale (gradation) scale. Hence in this study we have used Wilcoxon Signed Rank test to test efficacy of the drug. From the above table we can find out that the $\mathrm{P}$ value for pain, tenderness, discharge and granulation tissue floor parameters is less than 0.001 whereas $P$ value for size and depth of ulcer is between .001 and .05. Therefore, we can conclude that effect observed is significant.

\section{Overall effect of the therapy}

Table 3: Overall Result of the Study

\begin{tabular}{|l|l|l|l|}
\hline Sr.no & Result & No. of patients & Percentage \\
\hline 1 & Healed & 18 & $60 \%$ \\
\hline 2 & Markedly heal & 4 & $3.33 \%$ \\
\hline 3 & Moderately healed & 6 & $20 \%$ \\
\hline 4 & Mildly healed & 2 & $6.66 \%$ \\
\hline 5 & No improvement & 0 & 0 \\
\hline
\end{tabular}

On the basis of the specific scoring pattern adopted, the total effect of therapy had been assessed. Out of 30 patients 18 patients i.e. $60 \%$ were completely healed. 4 patients i.e. $3.33 \%$ were markedly heal, 6 patients i.e. $(20 \%)$ were moderately healed and 2 patients i.e. $6.66 \%$ were mildly healed after the completion of the course as well as follow up period.

\section{DISCUSSION}

Dushta Vrana is a commonly found ailment with a lower rate of recovery. Surgical intervention also does not cure the disease completely and the recurrence rate is also high. To avoid these hard times for a patient this study was conducted on Haridra Taila and Madhu to reduce the healing time and recurrence.

\section{Probable Mode of Action}

The probable mode of action of Haridra Taila and
Madhu on the Dushta Vrana is as follows-

\section{Removal of local "Dhatu Dushti":}

Severity of wounds depends on the local Dhatu Dushti with derangement of Sthanik Twaka (skin)and Mamsa Dhatu (muscle) with the involvement of Rakta Dhatu (blood). Haridra Taila possess the property of Tikta, Katu

Rasa, Rooksha Guna, Ushnavirya, Katuvipaka which are driving agents in actions like Chedana (removal, destruction), Lekhana, Shodhana, Kapha-Pitta Nashana (pacification), Vishanashana (antitoxic medication), Vedanashamana (analgesic), Twakdoshahara action. These properties of Haridra Taila enable it to remove or clean Dhatu Dushti. The drug also carries debridement action by the virtue of Lekhana Guna at the site of Dushta Vrana (wound /ulcer) and helped in the Shodhana of Dushta Vrana. 


\section{Effect on Clinical features:}

Earlier mentioned Rasa, Guna (s) \& Karma (s) of the trial drug helps to check out its effect on clinical features of the Vrana as follows-

1. Vatahara (Ushna Guna), Shothahara, antiinflammatory properties reduce the inflammation and thus helps to relieve the pain and tenderness. Shothahara property helped to reduce the swelling in the Vrana.

2. Shoshana karma of Tikta rasa and Rakta Shodhana and Krimighna karma helped to minimize the infection and Chedana and Lekhana Karma removed previous slough and prevents the formation of any new discharge, slough and secretions.

3. Unhealthy granulation tissue- Lekhana, Chedana, Raktashodhana Karma and Kaphapitta Shamakguna played an important role in removing out the debris and slough.

4. Rakta Shodhana (Tikta Rasa) Pittashamak, Varnya, Raktaprasadak actions improved the wound colour by improving the local circulation.

5. Infection- was prevented by the Krimighna, Vishaghna and Rakshoghna properties of the drug.

\section{Probable mode of action of Madhu}

Application of Madhu is mentioned as $57^{\text {th }}$ treatment modality in Shasti Upkarama given by Acharya Sushruta. Clinical observation made during study has shown its effectiveness in treatment of DushtaVrana. It has got properties like Shodhana, Lekhana, Sandhana, Ropana and Tridoshaghna. Honey is recommended as a traditional remedy in India from ancient years to treat skin conditions like eczema and skin infections.

The Vrana here was in Shudha Awastha for application of Madhu. Ropana Guna helps in healing of the Vrana and Lekhana, Shodhana and Tridoshaghana guna helps to alleviate the any Dosha imbalance later. Once the healthy granulation tissue appears application of Madhu which has Vranaropaka and Prasadana Guna, due to its Sukshma Guna, it gets readily absorbed. Thus, it is absorbed by the Vrana at cellular level and thus helps in faster growth of granulation tissue and henceforth healing. Due to its low water content microorganism does not grow in Madhu. Pure undiluted Madhu is hyperosmolar which is antibacterial in activity. Honey is acidic in nature with a $\mathrm{pH}$ 3.2-4.5. It prevents colonization and bacterial growth in wound tissue due to their acidic nature and thus keeps infection in control.

Honey contains glucose oxides an enzyme which produces Hydrogen Peroxide (H2O2), a known antiseptic. The amount produced is very less and thus acts like an antiseptic without producing any damaging effect of the Hydrogen peroxide used otherwise. Honey has been proved to be effective against organism esp. Staphylococcus aureus. Honey is especially useful against the multidrug resistant strain of organisms.

By virtue of the above said properties, wound healing with least of the scar tissue i.e. less fibrosis, colour almost similar to normal skin pigmentation, smooth, regular even surface was observed. Varnya, Twakaprasadana, Raktaprasadana actions of the Haridra Taila and Madhu lead to colour similar to the skin pigmentation.

\section{CONCLUSION}

In present clinical study Shodhana effect of Haridra Taila and Ropana effect of Madhu was evaluated against Dushta Vrana. Regarding signs and symptoms of DushtaVrana, Haridrataila and Madhu showed significant relief in pain, size, discharge, tenderness, depth of the ulcer and granulation tissue floor. It indicates effectiveness of above-mentioned drugs in improving the signs and symptoms of Vrana due to Shodhana effect of Haridra Taila and Ropana effect of Madhu.

This formulation is cost effective and provides complication free therapy.

\section{REFERENCES}

1. Sushruta: Sushruta Samhita, edited with Ayurvedatatva Sandeepika Hindi commentary by Shastri Kaviraj Ambika Dutta, Chaukhamba Sanskrit Sansthan publication, Varanasi India, Part 1:2006, Chikitsa Sthan 2/8 page no 18 .

2. Sushruta: Sushruta Samhita, edited with Ayurvedatatva Sandeepika Hindi commentary by Shastri Kaviraj Am- 
bika Dutta, Chaukhamba Sanskrit Sansthan publication, Varanasi India, Part 1:2006, Sutra Sthan 9/34 page no 195 .

3. Sushruta: Sushruta Samhita, edited with Ayurvedatatva Sandeepika Hindi commentary by Shastri Kaviraj Ambika Dutta, Chaukhamba Sanskrit Sansthan publication, Varanasi India, Part 1:2006, ChikitsaSthan 1/6 page no 3 .

4. Sushruta: Sushruta Samhita, edited with Ayurvedatatva Sandeepika Hindi commentary by Shastri Kaviraj Ambika Dutta, Chaukhamba Sanskrit Sansthan publication,Varanasi India, Part 1:2006, Chikitsa Sthan 1/58 page no 8.

5. Sushruta: Sushruta Samhita, edited with Ayurvedatatva Sandeepika hindi commentary by Shastri Kaviraj Ambika Dutta, Chaukhamba Sanskrit Sansthan publication, Varanasi India, Part 1:2006, ChikitsaSthan 1/130 page no 13 .

6. Shree Bhav Mishra praneet Bhavprakash preface Padmshree Prof Krishna Chandra Chunekar reprinted Choukambha Bharti Academy Varansi: 2010 ch Harikyadigana page no196 and 197

7. Niral Hansrajbhai Sojeetra, Mital M. Buha, Rabinarayan Acharya Haridra (Curcuma longa linn.) Depiction in Ayurvedic and Indian Alchemy (Rasashastra) Literature: A Classical Memoir 2019 https://www.researchgate.net/publication/333531644.

8. Experimental Investigation on efficient Supercritical CO2 Extraction of Essential Oil from Turmeric Rhizomes: Effects of Geometric and other Operation Parameters International Journal of Innovative Technology and Exploring Engineering (IJITEE) ISSN: 22783075, Volume-8 Issue-8 June, 2019 by Sutapa Roy, Chandan Guha, Asit Kumar Saha, Somak Jyoti Sahu page 325 .

\section{Source of Support: Nil \\ Conflict of Interest: None Declared}

How to cite this URL: Rathore Garima et al: Clinical Evaluation Of The Shodhana Effect Of Haridra Taila And Ropana Effect Of Madhu In Dushta Vrana. International Ayurvedic Medical Journal \{online\} 2021 \{cited May, 2021\} Available from: http://www.iamj.in/posts/images/upload/2872_2879.pdf 